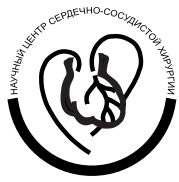

Учредитель и издатель

ФГБУ «ННПЦССХ им. А.Н. Бакулева»

Минздрава России

Лицензия на издательскую деятельность ИД № 03847 от 25.01.2001 г.

Свидетельство о регистрации средства массовой информации ПИ № ФС 77-19178 от 27.12.2004 г.

Все права защищены. Ни одна часть данного издания не может быть воспроизведена или использована в какой-либо форме, включая электронную или какие-либо иные способы воспроизведения информации, без предварительного письменного разрешения правообладателя, за исключением случаев краткого цитирования в научных статьях со ссылкой на источник.

Ответственность за достоверность информации, содержащейся в рекламных материалах, несут рекламодатели

Почтовый адрес редакции

119049, Москва, Ленинский пр-т, 8, ФГБУ «ННПЦССХ им. А.Н. Бакулева» Минздрава России, отдел интеллектуальной собственности

Зав. редакцией Радионова В.Ю.

Телефон 8 (499) 236-92-87

Факс 8 (499) 236-99-76

E-mail: izdinsob@yandex.ru

http://www.bakulev.ru

https://cardiology-journal.com

Лит. редактор, корректор

Кириленко А.М.

Компьютерная верстка и обработка графического материала

Матвеева Е.H.

Номер подписан в печать 23.03.2017

Формат 60×84 1/8

Печ. л. 11,25

Усл. печ. л. 10,8

Уч.-изд. л. 8,6

Печать офсетная

Тираж 500 экз.

Отпечатано в ФГБУ «ННПЦССХ им. А.Н. Бакулева» Минздрава России,

119049, Москва, Ленинский пр-т, 8

Креативная кардиология

2017; 11 (1): 1-90

Подписной индекс

АО «Агентство «Роспечать» 36797

ISSN 1997-3187

Журнал индексируется в следующих базах данных: Ulrich's International Periodical's Directory

Российский индекс научного цитирования Центр электронных ресурсов «Руконт» Агентство «Книга-сервис» Агентство «Пресс-Мед»
ФГБУ «Национальный научно-практический центр сердечно-сосудистой хирургии им. А.Н. Бакулева» Минздрава России

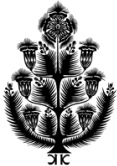 \\ Креативная \\ кардиология}

\author{
Рецензируемый научно-практический журнал \\ Выходит один раз в три месяца \\ Основан в 2007 г.
}

\section{7. $11(1)$}

\author{
Главный редактор \\ академик РАН и РАМН Л.А. Бокерия
}

\section{Редакционная коллегия}

Алекян Б.Г., д.м.н., профессор, академик РАН (Москва)

Алшибая М.М., д.м.Н., профессор (Москва)

Андреев Д.А., Д.м.н., профессор (Москва)

Асланиди И.П., д.м.н., профессор (Москва)

Барбараш О.Л., д.м.н., профессор, чл.-корр. РАН (Кемерово)

Булаева Н.И., канд. биол. наук (Москва)

Васильева Е.Ю., д.м.н., профессор (Москва)

Голухова Е.3. (заместитель главного редактора), д.м.н., профессор, академик РАН (Москва)

Гринштейн Ю.И., д.м.н., профессор (Красноярск)

Громова О.И. (ответственный секретарь), канд. мед. наук

(Москва)

Данилов С.М., д.м.н., профессор (Чикаго, США)

Драпкина О.М., Д.м.н., профессор, чл.-корр. РАН (Москва)

Космачева Е.Д., д.м.н., профессор (Краснодар)

Макаренко В.Н., д.м.н., профессор (Москва)

Марголис Л., д.м.н., профессор (США)

Медведева И.В., д.м.н., профессор, академик РАН (Тюмень)

Орлов М., д.м.н., профессор (Бостон, США)

Ревишвили А.Ш., д.м.н., профессор, академик РАН (Москва)

Серов Р.А., Д.м.н., профессор (Москва)

Синицын В.Е., д.м.н., профессор (Москва)

Сычев Д.А., д.м.н., профессор, чл.-корр. РАН (Москва)

Тутельян В.А., Д.м.н., профессор, академик РАН (Москва)

Фонякин А.В., д.м.н., профессор (Москва)

Хасин Й., д.м.н., профессор (Израиль)

Шпектор А.В. (заместитель главного редактора), д.м.н., профессор (Москва)

Журнал входит в перечень периодических рецензируемых научно-технических изданий, выпускаемых в Российской Федерации, рекомендуемых для опубликования основных результатов диссертаций на соискание ученой степени кандидата и доктора медицинских наук 